\title{
AN ANALYSIS OF DIRECT AND INDIRECT SPEECH ACTS PERFORMED BY MAIN CHARACTER IN THE MOVIE REVENANT SCRIPT
}

\author{
Fyngky Oktadistio \\ Bengkulu University \\ fyngkyoktadisio@gmail.com \\ Mazrul Aziz \\ Bengkulu University \\ Mazrulazizma@gmail.com \\ Zahrida \\ Bengkulu University \\ Zahridaadnan@gmail.com
}

\begin{abstract}
This Research Entitled "An Analysis Of Direct And Indirect Speech Acts Performed By Main Character In The Movie Revenant Script". This research was a descriptive analysis that discusses about direct and indirect speech acts in movie script entitled 'The Revenant.' In analyzing the script, there was used theory by Yule (1996). The data in this research based on main characters' utterances. The purpose of this analysis was to find out the types, and functions of speech acts whether it is direct speech act or indirect speech act in the movie script entitled 'The Revenant.' From the analysis, it was found that both direct speech acts and indirect speech acts are used by main characters in this movie. The most dominant type of speech act used in the movie script was direct speech act (13 utterances) and then followed by indirect speech act ( 9 utterances). The direct speech act was classified again into declarative type ( 2 utterances) imperative type (5 utterances) and interrogative type (6 utterances). Indirect speech acts was also classified again into declarative type ( 8 utterances) and Interrogative (1 utterance). For the functions, direct speech acts are classified into statement ( 2 utterances), order/request (5 utterances), and the last function of question (6 utterances). Indirect speech act also classified into question (9 utterances), and no functions of statement and order. Based on the result, the researcher found that Felicity Conditions and genre were the factors affected main characters in producing direct speech acts more than indirect speech acts.
\end{abstract}

Key words: Direct Speech Acts, Indirect Speech Acts, Movie. 


\begin{abstract}
Abstrak
Penelitian ini berjudul "Analisis tindak tutur langsung dan tidak langsung yang dilakukan karakter utama dalam skenario film berjudul Revenant ". Penelitian ini menggunakan analisis deskriptif yang membahas tentang tindakan langsung dan tidak langsung dalam naskah film berjudul 'The Revenant'. Dalam menganalisis naskah, ada Teori yang digunakan oleh Yule (1996). Metode yang digunakan dalam penulisan ini adalah metode deskriptif kualitatif. Data yang dianalisis dalam penelitian ini didasarkan pada ujaran karakter utama. Tujuan dari analisis ini adalah untuk mengetahui jenis, dan fungsi dari tindak tutur apakah itu tindak tutur langsung atau tindakan tidak langsung dalam naskah film berjudul 'Revenant'. Dari analisis tersebut, ditemukan bahwa tindak tutur langsung langsung maupun tindak tutur tidak langsung digunakan oleh karakter utama dalam film ini. Jenis tindak tutur yang paling dominan yang digunakan dalam naskah film adalah tidak tutur langsung (13 ujaran) dan kemudian dilanjutkan dengan tindak tutur tidak langsung (9 ujaran). Tindakan ujaran langsung diklasifikasikan kembali menjadi tipe deklaratif (2 ujaran) tipe imperatif (5 ujaran) dan tipe interogatif (6 ujaran). Untuk tindak tutur tidak langsung juga diklasifikasikan kembali menjadi tipe deklaratif ( 8 ujaran) dan Interogatif (1 ujaran). Untuk fungsi, tindak tutur langsung dikelompokkan menjadi pernyataan (2 ucapan), perintah / permintaan (5 ujaran), dan fungsi terakhir yaitu pertanyaan (6 ujaran). Tindakan tidak langsung juga dikelompokkan menjadi pertanyaan ( 9 ujaran), dan tidak ada fungsi pernyataan dan perintah. Berdasarkan hasil penelitian, peneliti menemukan bahwa kondisi kepuasan dan genre adalah faktor yang mempengaruhi karakter utama dalam menghasilkan tindak tutur langsung lebih banyak daripada tindak tutur tidak langsung.
\end{abstract}

Kata Kunci: Tindak tutur langsung, Tindak tutur tidak langsung, Film

\section{INTRODUCTION}

Communication deals with social activity which involves more than one person. It usually occurs between the speaker and the hearer (receiver). The words they utter are known as forms of language. Linguistics is one of disciplines about language. There are some fields of linguistics like phonology, morphology, syntax, semantics, and pragmatics. One of the important linguistic fields is pragmatics. Pragmatics studies the use of language by humans as determined by the condition of a society (Mey, 2006:6). It means the language that people use depends on the social condition where they live. The study of pragmatics includes context, deictic, presupposition, implicature, and speech acts. The speech act becomes the central points of pragmatics in this research.
According to Yule (1996:47), a speech act is generally defined as "an action via utterances". The utterances do not only contain the grammatical structures and words, but also contain the actions in the utterances.

According to Austin (1962: 94), speech act is everything which we do at the time of conversing or set of verbal discussion. Speech acts are not descriptive, instead they are pronounced to affect an actual situation. Speech acts usually do not refer to the past events. Speech act is the action performed by language to modify the state of the object on which the action performed. Speech act analysis can be applied in linguistics and literary works like poems, short stories, novels, movie and song. The dialogues in the literature can be analyzed by speech act, because we know that the 
main point of speech acts is the utterance or conversation. From this reason this research tries to find out some of speech acts analysis in a movie. In the movie of course it will be found in the conversation.

Speech acts can be classified into Direct Speech Act and Indirect Speech Act. Futhermore, Yule (1996) state that Direct Speech Act will happen if there is direct relationship between the structure and the function of the utterance. Meanwhile, Indirect Speech Acts will happen if there is indirect relationship between the structure and the function of the utterance. Relationship between the structure and the function of the utterances. For example,when someone says "it's cold outside", the direct speech act of this utterance is to inform the hearer about the real conditions outside, but the indirect speech act of this utterance is to request or to give command to close the door, so the cold will not affect the speaker.

When speaking every day, of course people will use different ways to express what are on their minds. Sometimes when they request something or produce utterance, they do not use a command expression or the purpose of what they say to each other and to the other is not clear. Besides in the real world, this phenomenon also occurs in literary works like movie.

Movie is a mass entertainment medium. It reflects the desires, needs, fears, and aspirations of a society (Allen and Gomery, 1985:154). As a social representation, movie derives its images, sounds, themes, and stories ultimately from their social environment. This research chooses a literary work of a movie The Revenant. In this year The Revenant become the most popular movie and wins Best Drama Category in Golden Globe Award 2016. The revenant is chosen by researcher because this movie is adapted from the real novel story by Michael Punke and the last sequel of two films before.

The aims of this study are to investigate the the types and function of direct and indirect speech acts performed by main characters in The Revenant Movie Script.

\section{METHOD}

The method used in this research is a qualitative method in terms of descriptive qualitative. This method can be applied because the writer observes the script of the Revenant movie and subtitle in collecting the data. Futhermore Hancock (2002:2) states that the qualitative method is concerned with developing explanation of a social phenomenon. This research describes the social phenomenon in understanding the meaning based on utterances. The main data in this research are the movie script in the The Revenant movie in which in form of the English subtitle. The data source or script taken from website (subscene.com). Besides, this research also uses the pictures of the movie when they are talking to describe the situation from the dialogue as the supporting of the main data. The researcher in this research hold roles in all of the activities of the research such as selecting the source of data, collecting the data, analyzing the data collected, and describing the findings of the research.

Meanwhile, a observation in to form of table checklist also needed as the secondary instrument. The researcher was helped by two experts to judge the instrument to gain a valid data. 


\section{RESULTS}

The first research question was what types of direct and indirect speech acts by the main characters. Here the briefly amount of types found from the data.

\begin{tabular}{|c|c|c|c|c|c|}
\hline \multirow{2}{*}{ No } & $\begin{array}{c}\text { Category } \\
\text { of speech } \\
\text { acts }\end{array}$ & \multicolumn{3}{|c|}{ Types (times) } & \multirow{2}{*}{ Total } \\
\cline { 3 - 5 } & Declarative & Imperative & Interrogative & \\
\hline 1 & Direct & 2 & 5 & 6 & 13 \\
\hline 2 & Indirect & 8 & - & 1 & 9 \\
\hline \multicolumn{4}{|l|}{ Total } \\
\hline
\end{tabular}

Table 1 shows there are three types of direct and indirect speech acts employed by the main characters. They are declarative, interrogative, and imperative. Furthermore, in the direct speech acts, interrogative was the most dominant type used by the main characters with 6 instances throughout the movie.

In process of analyzing the data, question mark became a hint used by researcher to identify this type. This type was used by main characters in order to get the information, or to know the state of a thing. Imperative occupies the second place among the other types. When using this type, main characters' utterance leads more to a directive or command addressed for the listener. Meanwhile, declarative was the least type of direct speech acts produced by the main characters. They are revealed only in 2 utterances out of total data utterances. The use of this type is related to utterance that contains lot of information. On the other words, main character produces this utterance to give a fact or opinion. All the above data were concluded as a direct speech because the relation of types does not violate the rules of direct speech acts.
Next, there are only two types of indirect speech acts performed by the main characters. They are declarative, and interrogative. Furthermore, the table presents that declarative was the most dominant type used by the main characters with 8 utterances throughout the movie. In this type, even though the speaker's utterance is informative, but the real aim is not just to declare something, but also to give a command, or request. For the last type of indirect speech acts expressed by main characters in The Revenant movie script was interrogative with only one time. In total, there were 9 utterances classified as indirect speech acts. All of the utterances above break the rule of direct speech acts, so it moved into indirect speech acts form.

For the functions, here the briefly amount of types found from the data.

\begin{tabular}{|c|c|c|c|c|c|}
\hline \multirow{2}{*}{ No } & \multirow{2}{*}{$\begin{array}{c}\text { Category of } \\
\text { speech acts }\end{array}$} & \multicolumn{3}{|c|}{ Functions (times) } & \multirow{2}{*}{ Total } \\
\cline { 3 - 5 } & Statement & Question & Order/request & \\
\hline 1 & Direct & 2 & 6 & 5 & 13 \\
\hline 2 & Indirect & - & - & 9 & 9 \\
\hline \multicolumn{4}{|l}{ Total } \\
\hline
\end{tabular}

The table above shows the three functions of direct and indirect speech acts employed by the main characters. They were statement, question and order/request. In the direct speech act tab number 1 , when producing the utterances, the main characters have some function which consist of 2 statements, 6 questions, and 5 orders/request. Question is the most function appeared in the data with 6 utterances. This function refers to the speaker to get information or desire. There were 6 data from main characters' utterances categorized as question. The next is function of order/request which refers to speaker instruction or desire at that time in producing the words. Then, 
the utterance of main characters which is categorized as statement consists of two data.

However, the number of functions of indirect speech is quite different. According to the table 2, It is found that main characters dominantly performed function of order/command than statement and question. It can be seen from the number of utterance that occur order/request is 9 utterances while no utterances consist of function of statement and question. The function of order/command in indirect speech act showed in the data $2,6,7,8,9,13,14$, 15,21 . From the table above, there was no utterance that is categorized as a statement and question, because The Revenant is an action movie, so the utterances of command and request were more effective and easy to understand by other characters. For more detail about functions, can be seen in the following table below.

\section{EXAMPLES OF TYPES AND FUNCTIONS FOUND IN THE DATA.}

\section{a. Direct Speech Acts}

a. 1 Direct Speech Acts in Imperative

Sentence Type as an

Order/Request.

Data Number 3 (03/00:08:15)

Context : Hawk and Glass are prepare to hunt a bear in forest, then suddenly hear a very loud voice from a distance.

\section{Hawk :Pa? What was that? \\ Glass : Lets go! Get to the boat son!}

Based on the conversation between protagonist main character named Glass and his son named Hawk. Hawk asked to his father what was going on, then Glass replied by saying "Lest go! Get to the boat!" Glass's bold utterance is a direct speech in types of imperative because the utterance directly commands hearer or Hawk to move and get to the boat. Based from Glass utterance, the function is order, Glass wanted his son to do what his said.

\section{a.2 Direct Speech Acts in Interrogative Sentence Type as an quesion.}

Data Number 1 (01/00:04:47)

Context : In the day first of hunting

Fitzgerald asked to Trapper about his

friend that he cannot find that

morning

Fitzgerald : You see Coulter ?

Trapper : Nope

The dialogue occurred in the middle of forest. Fitzgerald asked to Trapper about Coulter. Fitzgerald's bold utterance is a direct speech act in types of Interrogative because the utterance directly asking to the hearer. It is has a function of question because the utterance that is conveyed by Fitzgerald aims to get information.

\section{b. Indirect Speech Acts}

b.1 Indirect Speech Acts in Declarative

Sentence Type as an Order /

Request.

Data Number 2 (02/00:05:06)

Context : After the war ends against the Ree tribe, captain join to the wounded Fitzgerald and asked about his condition, thendiscussing what to do next. 
Captain : What are you thinking?

Fitzgerald : I hope, I dont need another shoot.

Captain : So, make sure we're ready to head out by dawn.

In the dialogue beside which is stated by Fitzgerald and captain, happened after a short clash with Ree tribe. Fitzgerald said to the captain that he did not need another shot. It showed by Fitzgerald's bold utterance. The strategy used in his or Fitzgerald's utterance is an indirect speech act, because this utterance known as declarative types but the function of this utterance is request. Fitzgerald stated something to captain, the utterance is not used to receive a comment by captain but it is a request for captain to stop clashing with Ree tribe.

\section{b.2 Indirect Speech Acts in \\ Interrogative Sentence Type as an Order/Request.}

Data Number 15 (15/00:43:47)

Context : Two men, they are Jim and Fitzgerald which taken a job to keep the

Glass that was badly wounded. After a few minutes Fitzgerald was distracted by the noise made by Jim.

\section{Fitzgerald : Will you quit that noise now ? Will you?}

Jim : Oh sorry

The bold sentence uttered by Fitzgerald to Jim is an indirect speech act. Fitzgerald asked to Jim to stop making a noise. This is a type of interrogative sentence and has a function of order. The purpose of the utterance is not related with the types of the utterance. Fitzgerald's bold utterance is about asking the question, but the purpose of Fitzgerald is to order Jim to quit the noise. A word "you" in this utterance indicates the type of interrogative, but the word "quit" shows the function of order or command.

\section{DISCUSSION}

According to Yule in his book Pragmatics (1996:55) direct speech acts will happen if there is direct relationship between the structure and the function of the utterance, while indirect speech acts will happen if there is no relationship between the structure and the function of the utterance. Yule also proposed 3 types of direct and indirect speech acts: Declarative, Imperative, and Interrogative. For the functions there are 3 functions: Statement, Question, and Order/Command. The results shows, direct speech acts with a frequency of 13 utterances appeared more than indirect speech acts that only have 9 utterances. For the detail, 13 utterances were included into direct speech acts with 2 Declaratives, 5 Imperatives, and 6 Interrogatives. Next, it was found 9 utterances were included into indirect speech acts 8 Declaratives, and 1 Interrogative.

For the types, first type of direct and indirect speech acts was imperative. In the data 3, Glass said "Let's go! Get to the boat son! Move!". In daily conversation this utterance is easier to understand because what is meant directly expressed from utterance itself. The main character shows an example of direct 
speech act in type of imperative, because his utterance ends by the exclamation mark. And the other sign that indicate for imperative is the words Go! and Move!. Another type of direct and indirect speech acts are interrogative. In the data 1 , when main characters said "Do you see Coulter?" the hearer quickly responded by saying nope. This type ends by question mark. The words "do you" indicated the speaker wanted to interrogate the listener. Declarative was the last type performed by main characters in this movie. In the data 17 , the main character, Glass said to Captain. "This horse looks strong." From the dialogue, it happened after Glass arrived in Fort Kiowa. Glass uttered a declarative sentence and the actual purpose of his utterance is stating that horse looks strong. Although the captain thinks that is not the purpose of what Glass's statement. In this dialogue the captain guesses that Glass wants to pursue Fitzgerald in the forest. But literally Glass only states his opinion about the horse in stable.

For the functions, Order/Request became the dominant function used by main characters in this movie. This function was referred to the speaker to get the information. For example, in the data number 4 , the main characters said "We got to get off this boat". Literally Glass gives the order, command, or instruction to the captain that they have to get off the boat. The aims/ or the function directly expressed from his utterance. Another function used in this movie was Question. This function appeared in the data number 5, Fitzgerald said to the Glass "Oh, then what do we do? Huh?" From the utterance, Fitzgerald interrogates Glass by giving the question. The function or the real aim is to get the information from Glass. Statement was the last function expressed by main characters in the Revenant Movie Script. In the data number 19, the main character, Glass said, "I was wondering if we could catch him in half a day." The function of this utterance was directly gave a statement about how long it takes to catch the Fitzgerald.

In this movie the main characters have dominantly expressed an example of direct speech acts. For example, when he said 'Let's go! Get to the boat son! Move!" In daily conversation this utterance is easier to understand because what is meant directly expressed from utterance itself. In the form of Direct Speech Acts, this utterance does not violate the rules of the Speech Acts itself, because there is a synchronous relationship between the type and function. If the type is imperative, so the function should be order. Moreover, the listener is easier to understand the purposes by looking at this sign. In different way, this utterance can be difficult to understand if the speaker or main character change it into indirect speech like "Do you feel something dangerous here?" at that time, maybe the hearer have another interpretation about the utterance, while the speaker or main character waits for the hearer to respond the command to move from the area. So, this type is changed from imperative into interrogative. For the function the utterance above has a function of order. This utterance can be classified as an Indirect Sentence because the interrogative type should not have any relation with the function of order. So, the relationship between type and function is the key in determining whether the utterance is a direct category or an indirect category, 
Based on the result, the researcher found that the three types and function of direct and indirect speech Acts proposed by Yule were used by main characters as their strategy in producing the utterance. One important point was the genre of this movie. The Revenant movie has a genre of action. This point gave an opportunity for main characters to produce words that are literally understood to the listener. In other words, main character did not express an utterance that made the hearer difficult to understand. The sincerity conditions also become another factor why characters employ such kind of direct speech acts. According to Yule in his book Pragmatics (1996:72) there are certain expected or appropriate circumstances know as felicity conditions, for the performance of speech acts to be recognized as intended. In this movie, the main characters expressed the utterance in accordance to what actually intended. When giving the question the real aims is to get an answer, when giving the command the real purpose is expecting the listener to do something. By affecting from this factor, they had dominantly in given direct speech acts rather that indirect speech acts. The results shows, direct speech acts with a frequency of 13 utterances appeared more than indirect speech acts that only have 9 utterances.

Comparing the previous study by Siti Zumaroh (2012) entitled "The Analysis Of Speech Act Used In "Air Force One Movie Script". She tried to find out what kinds of speech acts used in the movie by using Searle's theory in part of Illocutionary Acts. Then, she used the qualitative method. The result of the utterances showed the speech acts used were 53 representatives, 64 directives, 29 commisives, 17 expressives, and there were no declarative categories at the "Air Force One" movie script.

Similarly to the previous study conducted by Nurhidayah Permata Nurani (2015) with the title "A Pragmatic Analysis of Classroom Speech Acts in the English Teaching and Learning Process at SMA N 1 Purworejo. She used pragmatic theory that focuses on Illocutionary act and found the types of speech acts by Searle's theory. The main subject of the study was the English teacher of grade $\mathrm{X}$ IBB (Ilmu Budaya dan Bahasa) of SMA N 1 Purworejo. The result of the study showed that the most frequent speech act performed by the by the teacher was Directives during the four meetings of English teaching and learning activities which occurred in 440 utterances $(62.77 \%)$. On the other hand, commissives appeared to 116 be the least speech acts used by the teacher which only occurred in 7 utterances $(0.99 \%)$.

The similarity between the previous studies and this research is the application of Speech Acts that occurs in some subject like movie or daily interaction. But there is the different result in the analyzed data. The previous researcher focuses in analyzing the utterances in term of Illocutionary Acts based on Searle's Theory. While in this research, it is only focused in analyzing the utterances of direct and indirect speech acts based on Yule's theory. So, the result has different variation to the previous study even though the topic was same.

\section{CONCLUSION}

Dealing with the research questions of this research. The first question in this research was what types of direct and indirect speech acts found in The Revenant movie script. This research 
focuses on the utterances containing in direct and indirect speech acts. All the types of direct and indirect speech act were expressed by the main characters. It was found that total 22 utterances were included into types of direct and indirect speech acts. For the detail, 13 utterances were included into direct speech acts with 2 Declaratives, 5 Imperatives, and 6 Interrogatives. Next, it was found 9 utterances were included into indirect speech acts 8 Declaratives, and 1 Interrogative. The second question of this research was the functions of direct and indirect speech acts performed by main characters. From the results, the frequency of each functions of direct and indirect speech acts were 2 Statements, 6 questions, and 14 Orders/ Request.

In addition, the Felicity Conditions was one of the factors why the main characters in The Revenant Movie employ such kind of direct speech acts more than indirect speech acts. The other factor that affected main characters in producing direct speech acts was the action genre of the movie.

\section{REFERENCES}

Allen. R.C and D. Gomery. 1985. Film

History: Theory and Parctice.

New York: McGraw-Hill Inc.

Austin, J.L. (1962). How To Do Things

With Words. Cambridge, Mass:

Harvard University Press.

Hancock, Beverly. (1998). Trent Focus

for Research and Development in

Primary

Health Care: An Introduction to

Qualitative Research. Trent

Focus. Accessed 23 October

2013.

Nurhidayah Permata Nurani (2015). A

Pragmatic Analysis Of Classroom

Speech Acts In The English

Teaching And Learning Process

At Sma N 1 Purworejo.

Yogyakarta : Yogyakarta State

University.

J L Mey (2006), Pragmatics. Denmark:

University of Southern Denmark

Zumaroh, Siti (2012) .The Analysis Of

Speech Act Used In "Air Force

One” Movie Script”. Salatiga:

State Institute for Islamic Studies

(STA 